ДЕФІНІТИВНИЙ АНАЛІЗ СОЦІОКУЛЬТУРНОЇ КОМПЕТЕНТНОСТІ В КОНТЕКСТІ ПІДГОТОВКИ МАЙБУТНІХ БАКАЛАВРІВ ІНОЗЕМНОї МОВИ ${ }^{1}$

\title{
DEFINITIVE ANALYSIS OF SOCIO-CULTURAL COMPETENCE IN THE CONTEXT OF TRAINING OF FUTURE BACHELORS OF ARTS IN FOREIGN LANGUAGES
} У статті аргументовано, що безперервне i
щорічне збільшення міжкультурних контак-
тів і мобільність студентів, які навчаються
в різних країнах, передбачає розуміння осо-
бливостей міжкультурної комунікації в гло-
балізованому світі. Резюмовано, що в рамках
державних освітніх стандартів виокремлю-
ється кілька складників соціокультурної ком-
петентності, зокрема, розуміння власної
культури, осмислене уявлення про картину
світу іншої культури, позитивне сприй-
няття іноземної мови та їі носіїв, готов-
ність вирішувати конфллікти і суперечності,
а також уміння й навички вести міжкультур-
ний діалог.

Уточнено сутність змістового наповнення категорії «соціокультурна компетентність» у межах дослідження проблеми соормування соціокультурної компетентності майбутніх бакалаврів іноземної мови. Встановлено, що поняття «соціокультурна компетентність» часто розглядається науковцями крізь призму компонентного складу комунікативної компетентності майбутніх бакалаврів іноземної мови. Очевидно, що соціокультурний компонент виступає невід'ємною складовою частиною профресійної підготовки студентів цієї спеціальності. Зазначено, що зміст сочіокультурної компетентності демонструє ключову мету розвитку особистості майбутніх бакалаврів іноземної мови - формування в них здібностей і готовності бути активним учасником діалогу культур. Оволодіння соціокультурною компетентністю майбутніми бакалаврами іноземної мови передбачає ціннісне сприйняття загальнолюдської і національної культур, прагнення до іншомовної діалогічної комунікації з представниками інших народів і культур.

Враховано, що термінологічно безперервно оновлюються зміст і види профресійних компетенцій майбутніх бакалаврів іноземної мови. Це підкреслює інноваційну природу i практичний характер компетентнісного підходу в навчанні. Встановлено, що соціокультурна компетентність $є$ інтегративним інтелектуально-практичним утворенням, що містить взаємопов'язані соціокультурні знання, вміння $і$ навички ефективного комунікативного фрункціонування в процесі міжособистісного спілкування комунікантів. Встановлено, що зміст соціокультурної компетентності майбутніх бакалаврів іноземної мови відбивається у взаємозв'язку $і$ взаємозалежності низки компонентів, а саме: стратегічного, діяльнісного, когнітивного, змістовного $і$ афрективного.
Ключові слова: сочіокультурна компетентність, студенти, майбутні бакалаври іноземної мови, професійна підготовка.

The article argues that the continuous and annual increase of intercultural contacts and the mobility of students studying in different countries provides an understanding of the features of intercultural communication in the globalized world. It is summarized that within the framework of state educational standards several components of sociocultural competence are distinguished, in particular, understanding of one's own culture, meaningful perception of another culture, positive perception of a foreign language and its speakers, readiness to resolve conflicts and contradictions.

In the article the essence of the substantive content of the category of "sociocultural competence" is clarified in the process of overcoming the problem of forming socio-cultural competence of future bachelors of arts in foreign languages on the basis of interdisciplinary integration. It is established that the concept of "sociocultural competence" is often considered by scholars as an essential component of communicative competence of future bachelors in foreign languages. It is obvious that the socio-cultural component is an integral part of the professional training of students in this specialty. It is noted that the content of sociocultural competence demonstrates a key goal of developing the personality of future bachelors in foreign languages, the formation of their abilities and willingness to be an active participant in the intercultural dialogue. Developing sociocultural competence of future bachelors in foreign languages implies a valuable perception of international and national cultures, the desire for foreign-language dialogical communication with representatives of other peoples and cultures.

It is taken into account that the content and types of professional competences of future bachelors in foreign languages are constantly updated terminologically. This emphasizes the innovative and practical nature of the competence-based approach to learning. Sociocultural competence has been found to be an integrative intellectual and practical entity that contains interconnected sociocultural knowledge and the skill of effective cooperation in the process of interpersonal communication. It has been established that the content of sociocultural competence of future bachelors in foreign languages is reflected in the interconnection and interdependence of a number of components: strategic, cognitive, informative and affective.

Key words: sociocultural competence, students, future bachelors in foreign languages, professional training.

\footnotetext{
${ }^{1}$ Стаття виконана за сприяння програми Колегіум Талентум, 2019 р., Угорщина.
} 
Постановка проблеми у загальному вигляді. Соціально-економічна і політична специфіка розвитку сучасного українського суспільства сорормувала підстави, необхідні для відкритості в міжнародній комунікації, і вплинула на освітню політику загалом і на той її аспект, що стосується професійної підготовки майбутніх бакалаврів іноземної мови. Відмінною рисою сучасності $€$ необхідність переосмислення тієї глобальної мети, на вирішення якої орієнтується навчання іноземної мови як засобу для ефективних міжкультурних контактів.

Безперервне і щорічне збільшення міжкультурних контактів, мобільність молодих людей, які навчаються в різних країнах, передбачає розуміння особливостей міжкультурної комунікації в глобалізованому світі. Виникає потреба в необхідних знаннях у контактуючих сторін щодо культури та специсріки тієї чи іншої країни. Здебільшого увага дослідників зорієнтована на формування в студентів умінь комунікувати іноземною мовою. Проте нині іноземна мова виступає засобом здобуття соціокультурного досвіду представників іншої лінгвокультурної спільноти.

Практикою навчання іноземної мови було доведено, що інтерес до іншомовної культури пояснюється актуальною необхідністю успішного спілкування, яке неможливо зорганізувати без урахування особливостей культури країни, мова якої вивчається, для адаптації особистості до нових комунікативних контактів.

Як слушно зауважує Л. Вольнова [1], реальне спілкування підкреслює, що мовні засоби недоречно вважати єдиним інструментом розуміння. Тому в контексті нашого дослідження соціокультурну компетентність розглядатимемо як ключовий і сполучний елемент іншомовної комунікативної підготовки майбутніх бакалаврів іноземної мови. Актуальність проведеного нами дослідження підкреслюється необхідністю фрормування соціокультурної компетентності як важливого складника іншомовної підготовки і недостатнім рівнем розробки теоретичних і практичних аспектів для оптимального вирішення означеної проблеми.

Аналіз останніх досліджень і публікацій, в яких започатковано вирішення цієї проблеми, свідчить, що формування соціокультурної компетентності майбутніх фрахівців, шляхи і методи вирішення цього питання привертали увагу багатьох науковців. Зокрема, дослідники сорокусували свою увагу на виокремленні соціокультурних стереотипів (Г. Соловайнен [7]), дослідженні питання взаємодії мови і культури (І. Закір'янова [2]), конкретизації методологічних підходів до формування соціокультурної компетентності (Л. Вольнова [1], М. Максимець [4], Є. Подольська [5], Н. Чернуха [8]) та ін.

Мета статті - окреслення змістового наповнення категорії «соціокультурна компетентність» у межах дослідження проблеми фрормування такого френомена в майбутніх бакалаврів іноземної мови на засадах міждисциплінарної інтеграції.

Виклад основного матеріалу. У рамках державних освітніх стандартів виокремлюється кілька складників соціокультурної компетентності, зокрема, розуміння власної культури, осмислене уявлення про картину світу іншої культури, позитивне сприйняття мови, що вивчається, та її носіїв, готовність вирішувати консрлікти і суперечності, а також уміння й навички вести міжкультурний діалог. 3 кожною наступною редакцією стандартів освіти проблемі формування соціокультурної компетентності майбутніх фрахівців, зокрема бакалаврів іноземної мови, надається дедалі більшого значення. Тому нині відбуваються певні зміни також і у вищій школі, де зростає увага до методичних аспектів формування соціокультурної компетентності майбутніх фрахівців під час навчання іноземних мов.

Практика навчання іноземної мови та аналіз найбільш часто використовуваних навчальних посібників доводять, що цілі фрормування соціокультурної компетентності вирішуються фррагментарно, що $€$ неприпустимим із позиції сучасних вимог до іншомовної підготовки майбутніх бакалаврів іноземної мови.

Нині очевидно, що під метою навчання іноземної мови розуміється комплексна проблема, в якій окреслюється низка завдань, одним з яких $€$ формування соціокультурної компетентності в студентів. Звертаючись до розгляду теоретичних передумов розуміння поняття «соціокультурна компетентність», можемо стверджувати, що оволодіння такою компетентністю дає змогу майбутнім фрахівцям:

- оволодіти активною життєвою та профресійною позицією, що детермінує здатність до професійної самореалізації в іншомовному середовищі;

- забезпечити адекватну готовність до входження у відкрите інформаційне співтовариство, в глобалізований світ і адаптуватися в ньому;

- виховувати в собі толерантність, фрормувати навички ведення діалогу для встановлення взаєморозуміння з іншомовним співрозмовником.

Теоретичний аналіз наукової літератури з проблеми дослідження засвідчив, що поняття «соціокультурна компетентність» часто розглядається науковцями крізь призму компонентного складу комунікативної компетентності майбутніх фрахівців іноземної мови. Очевидно, що соціокультурний компонент виступає невід'ємним складником професійної підготовки студентів такої спеціальності, особливо в контексті навчання іноземної мови інших. Звертаючись до розуміння соціокультурної компетентності, треба зазначити, що ії зміст демонструє ключову мету розвитку особистості майбутніх бакалаврів іноземної мови - фрормування в них здібностей і готовності бути активним учасником діалогу культур. 
В основі комунікативної взаємодії дослідники зазвичай виокремлюють принципи кооперації, взаємоповаги, терпимості до відсутності культурної ідентичності, подолання культурних відмінностей та ін. Так, вітчизняні науковці (М. Максимець [4], $€$. Подольська [5]) підкреслюють важливість наявності в кожного учасника комунікації власного багажу іншомовної та культурної підготовки, що створює індивідуальне розуміння картини світу, яка певною мірою не ідентична іноземній (так званий чужий образ свідомості). Це створює умови для формування готовності до іншомовної діалогічності, що наділяє майбутніх бакалаврів іноземної мови здібностям вести діалог культур. Отже, залучення майбутніх бакалаврів іноземної мови до іншої культури в рамках діалогу культур передбачає необхідність спиратися на знання своєї культури в контексті отримання знань про іноземну культуру й усвідомлення її ключових понять і особливостей.

Виникнення поняття «соціокультурна компетентність» пов'язане 3 роботою Ради Європи 3 культурного співробітництва, де цей термін розглядається як один із компонентів комунікативної компетентності і визначається як «здатність до адекватної взаємодії в ситуаціях повсякденного життя, встановлення і підтримання соціальних контактів за допомогою іноземної мови» [8, с. 140].

Сучасні науковці (Л. Вольнова [1], І. Закір'янова [3] та ін.) трактують соціокультурну компетентність як поєднання знань, навичок і вмінь, здібностей і якостей, які фрормуються в процесі міжкультурної комунікації, як сукупність знань про країну, мова якої вивчається, «національно-культурні особливості соціальної та мовної поведінки носіїв мови і здатність користуватися такими знаннями в процесі спілкування, дотримуючись звичаїв, правил поведінки, норм етикету, соціальних умов і стереотипів поведінки носіїв мови» [3, с. 286].

$€$ думка, що соціокультурна компетентність фрормується в умовах соціокультурної освіти. В умовах такого навчання майбутні бакалаври іноземної мови мають змогу опанувати вміння і навички міжкультурного спілкування. Очевидно, що організація оптимального міжкультурного спілкування потребує від його учасників володіння базовим об'ємом соціокультурних знань щодо культур різного мовного середовища, а також ключових навичок і вмінь, необхідних для успішної комунікації. Для оптимального забезпечення соціокультурної освіти використовується соціокультурний підхід, який сприяє визначенню практичної стратегії вивчення іноземної мови.

Розгляд теоретичних основ соціокультурної компетентності передбачає також використання поняття «культура» - складного багатоаспектного френомена, що досліджується різними гуманітарними науками (культурна антропологія, етнологія, етнографрія, культурологія та ін.). Означені наукові галузі торкаються загального кола таких питань, як людина і навколишній світ, міжкультурна взаємодія, виникнення культури та її трансорормації, а також інших питань, які мають культурні складники.

Таким чином, теоретичний аналіз наукової літератури дає змогу розуміти соціокультурну компетентність майбутніх бакалаврів іноземної мови як цілісну систему, яка має певну цілісну структуру, що містить низку складників із певними характерними інтегративними властивостями, які неможливо звести до суми властивостей кількох компонентів.

Оволодіння соціокультурною компетентністю майбутніми бакалаврами іноземної мови передбачає ціннісне сприйняття загальнолюдської і національної культур, прагнення до іншомовної діалогічної комунікації 3 представниками інших народів і культур. На цій основі активізуються процеси самоідентифікації та глибшого усвідомлення власної культури в порівнянні з іншою культурою і народом, мова якого вивчається. Цілісність соціокультурної компетентності надає змогу учасникам міжнародної комунікації також зрозуміти почуття і думки іншого народу та подолати національний культуроцентризм.

Теоретичний аналіз наукових джерел свідчить, що в педагогічній науці дискусійними є питання стосовно структурних складників соціокультурної компетентності майбутніх бакалаврів іноземної мови та їхнього змістовного наповнення. Здебільшого серед основних компонентів, що виокремлюються в структурі соціокультурної компетентності, називаються соціокультурні знання енциклопедичного і фронового характеру, які відображені в конкретному мовному матеріалі, та способи їх використання, що залежать від сорери застосування, характеру ситуації, а також теми спілкування. Крім того, науковці підкреслюють, що досвід спілкування та особистісних відносин учасників процесу спілкування $є$ найважливішим компонентом соціокультурної компетентності, оскільки зумовлює наявність вже сорормованих умінь і навичок [7].

Десрінітивний аналіз соціокультурної компетентності передбачає уточнення сутності окремих складників цього феномена в майбутніх бакалаврів іноземної мови, наприклад, змістовного, діяльнісного, когнітивного, стратегічного та афективного. Кожен з означених елементів володіє яскраво вираженим соціокультурним забарвленням, що знаходить відображення в їхній характеристиці.

Що стосується змістовного і когнітивного компонентів, то в рамках соціокультурної компетентності майбутніх бакалаврів іноземної мови вони можуть розглядатися крізь призму певних енциклопедичних знань щодо культури, культурних цінностей і традицій, особливостей національного менталітету, традиційної тематики спілкування, засобів і методів уявлення ціннісних орієнтирів своєї країни 
і країни, мова якої вивчається, а також картини світу студентів, умінь розпізнавання полікультурної реальності у формуванні певної картини в культурних концептах, що представляють культурно значущу інформацію, тобто спрямовуються на формування вторинної мовної особистості.

Стратегічний і діяльнісний компоненти відображають ступінь сфрормованості в майбутніх бакалаврів іноземної мови навичок враховувати сореру, тематику й обставини спілкування, здатності застосовувати отримані знання в іноземній мовній діяльності, спираючись у своєму спілкуванні на адекватний мовний матеріал (відповідні мовні навички) і різні мовні вміння, застосовуючи при цьому конкретні соціокультурні знання, а також здатність і готовність вступати в контакт 3 іншомовним співрозмовником, знання техніки та прийомів спілкування, прийнятих у країні мови, що вивчається тощо.

Значну роль у розглянутому аспекті відіграє розуміння того, що в рідній та іноземній мові існують як подібності, так і відмінності, що зумовлюють існування неідентичних соціокультурних явищ. У процесі освоєння відповідного культурного досвіду носіїв іншої мовної та культурної системи відбувається становлення і формування досвіду наслідувати і поважати норми іносоціуму, підсвідомо протиставляючи їх особливості своїй культурі. Такому елементу притаманне володіння компенсаторними вміннями (для заповнення в прогалинах лінгвістичного коду), навчальними і дослідницькими стратегіями, які забезпечують вдосконалення у володінні іноземною мовою та здатність вивчати інші мови і культури.

Афрективний компонент представлений у вигляді застосування комунікативного досвіду в процесі тієї чи іншої іншомовної мовленнєвої діяльності, врахування особистісних взаємин із комунікантами, об'єктивне ставлення до матеріальних і духовних цінностей іншої культури, вибір прийнятного стилю спілкування, толерантність і емпатію.

Безумовно, перераховані нами компоненти соціокультурної компетентності не є загальновизнаними і єдино вірними, оскільки як у вітчизняній науці, так і в закордонній є ціла низка психолого-педагогічних підходів до розуміння сутності згаданої компетентності. Така різниця поглядів зумовлена різним розумінням як міжкультурної комунікації, так і, власне, соціокультурної компетентності та її положення у структурі профресійних знань, умінь, навичок майбутніх бакалаврів іноземної мови. Водночас розширення структури соціокультурної компетентності, що розглядається в контексті іншомовного спілкування і комунікації між представниками різних культур, дає змогу поглибити дефінітивний аналіз розглянутого френомена.
Варто зауважити, що єдність поглядів у змісті такої складної і важливої компетентності майбутніх бакалаврів іноземної мови практично неможлива. Це зумовлено швидким темпом змін умов і вимог професійної освіти до змісту навчання майбутніх бакалаврів іноземної мови, відповідно, і до розуміння сутності соціокультурної компетентності. Орієнтація української системи освіти на реалізацію компетентнісного й особисто-орієнтованого підходів, а також сучасне міжнародне становище нашої країни на світовій арені дають змогу говорити про «рухливість» структури соціокультурної компетентності майбутніх бакалаврів іноземної мови, що розвивається в прямій залежності від соціально-економічної ситуації. Поряд із появою нових і специфрічних складників соціокультурної компетентності відбувається й уточнення сутності цієї важливої характеристики у професійній підготовці майбутніх бакалаврів іноземної мови.

Висновки. Таким чином, у процесі розгляду теоретичних основ дослідження проблеми формування соціокультурної компетентності майбутніх бакалаврів іноземної мови на засадах міждисциплінарної інтеграції встановлено, що термін «компетентність» у світлі дослідження відображає комплекс знань, умінь і навичок мовця/слухача для їх використання в мінливих комунікативних ситуаціях міжкультурної взаємодії. Термінологічно безперервно оновлюється зміст і види професійних компетенцій майбутніх бакалаврів іноземної мови, що підкреслює інноваційну природу і практичний характер компетентнісного підходу в навчанні. Встановлено, що соціокультурна компетентність $€$ інтегративним інтелектуально-практичним утворенням, що містить взаємопов'язані соціокультурні знання, вміння і навички ефективного комунікативного функціонування в процесі особистісного спілкування комунікантів. Встановлено, що зміст соціокультурної компетентності майбутніх бакалаврів іноземної мови відбивається у взаємозв'язку і взаємозалежності низки компонентів, а саме: стратегічного, діяльнісного, когнітивного, змістовного й афективного.

Перспективи подальших розвідок у цьому напрямі вбачаємо в дослідженні соціально-культурних передумов модернізації професійної підготовки майбутніх бакалаврів іноземної мови в умовах оновлення педагогічної освіти на засадах міждисциплінарної інтеграції.

\section{БІБЛІОГРАФІЧНИЙ СПИСОК:}

1. Вольнова Л.М. Соціокультурна компетентність як складова підготовки студентів - майбутніх фрахівців системи діяльності «людина-людина». Науковий часопис НПУ імені М.П. Драгоманова. 2009. Вип. 28 (52). С. 137-145.

2. Закір'янова І.А. Динаміка соціокультурної компетентності майбутніх педагогів. Тео- 
ретичні питання культури, освіти та виховання : збірник наук. праць. Київ : Вид. центр КДЛУ, 2002. Вип. 21. С. 183-Закір'янова І.А. Формування соціокультурної компетентності у майбутніх вчителів іноземної мови в процесі профресійної підготовки : автореф. дис. ... канд. пед. наук : 13.00.04. Київ, 2006. 23 с.

3. Максимець М. Формування соціокультурної компетенції у процесі вивчення іноземної мови. Вісник Львівського університету. Серія педагогічна. 2006. Вип. 21. С. 211-218.

4. Подольська Є.А. Освіта як чинник розвитку особистості в соціокультурному контексті : монографрія. Харків : Вид-во НФАУ : Золоті сторінки, 2002. 236 c.
5. Саволайнен Г.С. Модель социокультурной компетентности преподавателя высшей школы. Вестник Сибирского государственного аэрокосмического университета им. академика М.Ф. Решетнева. 2006. T. 3. C. $159-162$.

6. Саволайнен Г.С. Социокультурное взаимодействие в образовательном процес се педагогического вуза и школы : обновление содержания, технологий подготовки и мониторинга : монография. Красноярск : Краснояр. гос. пед. ун-т им. В.П. Астафьева, 2005. 316 c.

7. Чернуха Н.М., Мурзіна А.В. Умови фрормування соціокультурної компетентності майбутніх учителів фрілологів. Вісник ЛНУ імені Тараса Шевченка. 2009. № 9 (172). С. 165-173. 